\title{
Sustainable Digital Governance vis-à-vis Employees' Perspective: Empirical Evidences from Indian Higher Education
}

\author{
Prof. Sanket Vij ${ }^{*}$ and Priya Vij ${ }^{2}$ \\ ${ }^{I}$ Department of Management Studies, BPSMV, Khanpur Kalan,eMail:sanketvij@gmail.com \\ ${ }^{2}$ Scholar, Department of Computer Sciences and Applications, MDU, Rohtak, eMail:pvij40@gamil.com \\ *Corresponding author. Email: sanketvij@gmail.com
}

\begin{abstract}
The present study comparatively analyzes digital governance services of Indian Higher Education Institutions (HEIs) from employees' perspective. Digital governance services of five prominent Indian HEIs established by central and state governments were analyzed empirically from employees' (back and front end digital governance service providers) perspective. Five dimensions were extracted on the basis of extensive literature review, models, NeSDA \& UNDESA methodology and through Confirmatory Factor Analysis (CFA). Responses of 100 back and front end digital governance service providers, working at different levels in Central and State Universities of India, were collected through in-depth personal interviews and observation checklist. The study highlights the status of digital governance services and major factors liable for structural gaps. The study concludes that for sustainable digital governance, progressive services involvement of employees' must be ensured from planning phase. The outcome of the study would assist and guide the policy makers, developers and administrators of Indian HEIs to accredit the employees' perspective to achieve good and sustainable digital governance.
\end{abstract}

Keywords: Digital Governance, Digital Divide, Digital Society, Employees, Sustainable Development Goals.

\section{INTRODUCTION}

The rapid advancement of technology supported by augmented knowledge, capacity and expectations of the citizens have actuated establishments' viz. governments, organizations and institutions, to integrate technology into governance initiatives for attaining Sustainable Development Goals (SDGs) and good governance and transitioning into digital society. During the last few years, the way the establishments connect, interact, and transact with stakeholders have been transformed completely and significant impact of digitalization of governance process is evident.

Barbosa [1] established that inclusiveness, trustworthiness, and transparent mechanisms along with accountability can be achieved through digital governance mechanisms. “..Digital governance focuses on clear accountability for digital strategy, policy, and standards - Welchman.." [2]. Opening governance processes had purgative effect and led to development of integrated digital governance [3].
SDGs are inseparable from secure, equitable and trusted digital world. Digital technologies are a major force driving changes in, both, society and environment required to attain SDGs, and are capable of mitigating the negative impact of current pandemic i.e. COVID-19 economically, socially and environmentally [4]. Attaining SDGs through digital governance demands for strategic alignment among all the constituents [5].

Deployment of state-of-the-art technology in governance is essential to attain SDGs. However, technological advancement could have adverse effect on SDGs' pledge to 'leave no one behind' as the latest and modern technology is often available only to the well-off and could exclude the most vulnerable in society [6]. "..Technology has great potential to help deliver the SDGs, but it can also be at the root of exclusion and inequality - Antonio Guterres..." In addition, novel challenges viz. digital divide, digital isolation, equitable growth, digital trust and security etc. also emerged from the transition to a digitally driven society [7]. Further, gap between SDGs 
aspiration and Digital Governance Competence (DGC) affects outcome significantly [8].

Political leadership, willpower [9], vision, mission along with Integration of governance with sustainability [10] and use of adaptive governance approach [11] is required to bridge the gap between digital transformation of governance and address the economic and social sustainability challenges of digitalization. This paradigmatic shift shall address the challenges of employees (back and front end) providing digital governance services to stakeholders' [12]. Strategic actions are planned at top level and there is a need to rethink and focus on the employees' involvement and actions [13]. Digital skills of service providers have significant impact on diffusion of sustainable digital governance. Back-end factors are of eminent importance at all stages of digital governance [14] and employees also face digital challenges that accordingly require consistent guidance and training. These play a key role in sustainability of digital governance. Further, employees need to be a part of shared vision rather than just getting impacted with the outcomes of digital governance $[15,22]$.

Emphasis of digital governance shall be on sustainable development along with analyzing unanticipated effects of disruptive technologies [16] rather than on adoption of lucrative state-of-the-art technology and infrastructure [17,20]. Collaborative efforts of employees is vital for the success of digital governance rather than infrastructure, technology and process $[18,21]$. Research studies concur with the profound positive impact of digital governance in attaining progressive, equitable and sustainable growth, but, conflicting research outcomes have also been reported, especially from employees' perspective, making it imperative for more empirical studies to address this issue. Surprisingly, only few studies examined the major issues concerning digital governance in Indian Higher Education Sector (HEIs). With this in view, the present study was conducted to empirically assess the sustainable digital governance services from employees' (back and front end service providers) perspective.

\section{RESEARCH METHOD AND EQUATIONS}

With the proclamation of eKranti and Indian National Education Policy - 2020 (NEP), the anticipated contribution of digital governance in HEIs to provide sustainable, transparent and efficient progressive services has been enhanced. Conversely, significant gaps are practically evident in research outcomes. Consequently, the enormous failure rate of digital governance initiatives coupled with research gaps necessitates for a rapid and consistent horizontal and vertical assessment from employees', i.e. Back and Front end service providers, perspective. National e-Governance Service Delivery Assessment 2019 (NeSDA) [19] of India assessed digital governance services portals of six sectors (Finance, Labour \& Employment, Education, Local Government \& Utilities, Social Welfare, Agriculture, Health and Environment) from citizen's perspective and evinced a low level of citizen satisfaction, particularly related to the education sector. This demands for an assessment of digital governance initiatives of HEIs from employees' (Back and Front end service providers) perspective to ascertain major factors liable for structural gaps.

Five dimensions were extracted on the basis of extensive literature review, models, NeSDA and UNDESA methodology and through Confirmatory Factor Analysis (CFA) i.e. Performance Expectancy (.743), Compatibility (.778), Job Fit (.701), Facilitating Conditions (.883) and Intention to Use (.957). The assortment of WebQual Index, SERVQUAL, SITEQUAL, and eQual methodology was used to develop a methodology to assess the digital governance initiatives of HEIs from employees' perspective and also to ascertain major factors liable for operational gaps.

Five prominent Central and State Universities/Institutes of India i.e. Malaviya National Institute of Technology - Jaipur (MNIT), National Institute of Technology - Kurukshetra (NITK), Guru Nanak Dev University -Amritsar (GNDU), Maharshi Dayanand University - Rohtak (MDU), and Bhagat Phool Singh Mahila Vishwavidyalaya - Sonipat (BPSMV) have been included as testing units. Responses of 100 Back and Front End digital governance service providers, working at different levels in Central and State Universities of India, have been collected through in-depth personal interviews and observation checklist. Employees having more than five years of experience in digital governance services and ready to interact and participate in the study were contacted through snowball method and selected through judgment sampling. The diversity of HEIs and respondents has been ensured for inclusive analysis.

\subsection{Ethical Aspects}

The respondents were apprised regarding objective of the research before starting the 
interview. Further, the respondents were assured that their identity shall not be revealed.

\subsection{Demographic Status}

Out of 100 employees (back and front end), 52 $(52.0 \%)$ were females and $48(48.0 \%)$ were males; $46(46.0 \%)$ were Post-graduates (25 females and 21 male), $29(29.0 \%)$ were Ph. D. (12 females and 17 males) and remaining $25 \quad(25.0 \%)$ were undergraduates (15 females and 10 males); 21 $(21.0 \%)$ were serving as Assistants, $20(20.0 \%)$ as Head of Departments/Branches, $20(20.0 \%)$ as Deans, $16(16.0 \%)$ as Assistant Registrars, 14 $(14.0 \%)$ as Superintendents and $9(9.0 \%)$ as Deputy Registrars.

\section{ANALYSIS AND INTERPRETATIONS}

To assess the status of sustainable digital governance services from employees' perspective exhaustive analysis has been carried out in two phases: In the First phase GAP score of employees has been assessed on the basis of five dimensions of digital governance; and in the second phase reasons of structural GAP were identified. Overall, 88 $(88.0 \%)$ employees informed that technology purchase related to digital governance and was decided by top level management; and remaining 12 $(12.0 \%)$ accepted that decision was taken by middle level management. Surprisingly, no involvement of end service provider was evident in technology purchase decision. Further, 58 (58.0\%) employees admitted that technology purchase decision was a group decision and remaining $42(42.0 \%)$ believed it to be an individual decision. Moreover, 92 (92.0\%) employees confirmed no involvement of end user in technology purchase decision. Figures and tables should be placed either at the top or bottom of the page and close to the text referring to them if possible.

Table 1: Overall Employees GAP Score

\begin{tabular}{|ll|l|l|}
\hline & & $\overline{\mathrm{x}}$ & $\sigma$ \\
\hline $\begin{array}{l}\text { Overall } \\
\text { Score }\end{array}$ & Unweighted GAP & 0.0165 & 0.395 \\
\hline $\begin{array}{l}\text { Overall Weighted GAP } \\
\text { Score }\end{array}$ & 0.9055 & 7.975 \\
\hline
\end{tabular}

Overall employees' response score is in positive zone (Table 1) which affirms the positive perspective of employees towards digital governance services. The analysis revealed that Intention to use (23.86) was accorded maximum weight, followed by Performance Expectancy (19.10), Job Fit (19.04), Compatibility (18.98) and Facilitating Conditions (18.97), by the employees which portrays that the employees are ready to compromise on Compatibility and Facilitating Conditions dimensions to provide better digital services for sustainable development. For small tables, please place it within a column and bigger table be placed in a text frame spanning to both columns. Use the Table facility available within the MSWord. The font in the row header should be bold and you can use the style available from the style palette.

Table 2: Overall Dimension wise GAP Score of Employees

\begin{tabular}{|l|l|l|l|l|l|}
\hline & $\begin{array}{l}\text { Performance } \\
\text { Expectancy }\end{array}$ & Compatibility & Job Fit & $\begin{array}{l}\text { Facilitating } \\
\text { Conditions }\end{array}$ & $\begin{array}{l}\text { Intention } \\
\text { to Use }\end{array}$ \\
\hline Overall Unweighted GAP Score & 0.0224 & 0.9466 & 0.5166 & -2.0032 & 0.5993 \\
\hline Overall Weighted GAP Score & 0.434 & 17.8732 & 9.91 & -37 & 14.2984 \\
\hline
\end{tabular}

Further, employees were satisfied with all dimensions except Facilitating Conditions, i.e. overall average un-weighted GAP Score was -2.0032 and weighted GAP Score was -37 (Table 2). The analysis affirms that this extreme dissatisfaction has significant negative impact on the employees' perspective towards the role of digital governance for sustainable development.

The comparative analysis of HEIs revealed (Table 3) that the employees rated quality of digital governance services of MDU (Unweighted GAP score .0602 and Weighted GAP score 1.9706) highest; BPSMV and GNDU were in positive zone;
MNIT (Unweighted GAP score -.0177) and NITK (Unweighted GAP score -.0035) were in negative zone. This explains that the employees' perspective at MNIT and NITK, towards use of digital governance for sustainable development was negative.

Table 3: Comparative GAP Score of HEIs

\begin{tabular}{|l|l|l|}
\hline HEI & $\begin{array}{l}\text { Unweighted } \\
\text { GAP Score }\end{array}$ & $\begin{array}{l}\text { Weighted GAP } \\
\text { Score }\end{array}$ \\
\hline BPSMV & .0340 & .9497 \\
\hline GNDU & .0088 & .9982 \\
\hline
\end{tabular}




\begin{tabular}{|l|l|l|}
\hline MNIT & -.0177 & .0511 \\
\hline NITK & -.0035 & .5567 \\
\hline MDU & .0602 & 1.9706 \\
\hline
\end{tabular}

It is clearly evident that the employees of all the HEIs were highly unsatisfied with Facilitating Conditions dimension of digital governance which indeed is vital for providing efficient services. Further, the testing value (One-Way ANOVA) related to "No significant difference exists between HEIs employees' perspective related to use of digital governance services for sustainable development" (H0) (Table 4 and 5) reveled that null hypotheses was accepted which affirms that all the employees have similar assessment regarding use of digital governance for sustainable development. A comparison of the HEIs also endorsed the same results.

Table 4: One-Way ANOVA

\begin{tabular}{|l|l|l|l|l|}
\hline & $\mathrm{F}$ & $\mathrm{df1}$ & $\mathrm{df2}$ & $\mathrm{p}$ \\
\hline $\begin{array}{l}\text { Overall Unweighted } \\
\text { Gap Score }\end{array}$ & 0.120 & 4 & 95 & 0.974 \\
\hline $\begin{array}{l}\text { Overall Weighted } \\
\text { Gap Score }\end{array}$ & 0.152 & 4 & 95 & 0.961 \\
\hline
\end{tabular}

Table 5: Dimension wise Comparative Analysis of HEIs
The results of social engineering penetration testing method discovered seventeen factors liable for operational and structural gaps (coded as R1 to R17) and depicted that on overall basis "Working Environment and Service Vision" (4.11) was considered the major reason of Operational GAP between digital governance services and achievement of sustainable services. The high mean value of "G2C eGovernance progressive services launched without strategy", "G2C eGovernance progressive services launched without end user input", "Insufficient or Inappropriate Information", "No integration of top down leadership and employees efforts", "G2C eGovernance progressive services considered as an it project - not education initiatives leveraging technology" and "G2C eGovernance progressive services strategy is not vital for HEI strategy" also indicated that the employees acknowledged these as the foremost hindrances towards achieving sustainable efficient digital governance services. One-Way ANOVA value (Table 6) showed that "strong association exists between employees' perspective and identified structural gaps of digital governance" (H1)

\begin{tabular}{|c|c|c|c|c|c|}
\hline & $\begin{array}{l}\text { Performance } \\
\text { Expectancy }\end{array}$ & Compatibility & Job Fit & $\begin{array}{l}\text { Facilitating } \\
\text { Conditions }\end{array}$ & $\begin{array}{l}\text { Intention } \\
\text { to Use }\end{array}$ \\
\hline $\begin{array}{l}\text { Overall Score Construct wise Unweighted } \\
\text { GAP Score }\end{array}$ & 0.0224 & 0.9466 & 0.5166 & -2.0032 & 0.5993 \\
\hline $\begin{array}{l}\text { Overall Score Construct wise weighted } \\
\text { GAP Score }\end{array}$ & 0.434 & 17.8732 & 9.91 & -37 & 14.2984 \\
\hline $\begin{array}{l}\text { BPSMV Construct wise Unweighted GAP } \\
\text { Score }\end{array}$ & 0.037 & 0.882 & 0.849 & -2.016 & 0.415 \\
\hline $\begin{array}{l}\text { BPSMV Construct wise Weighted GAP } \\
\text { Score }\end{array}$ & 0.737 & 16.390 & 16.100 & -38.440 & 9.961 \\
\hline $\begin{array}{l}\text { GNDU Construct wise Unweighted GAP } \\
\text { Score }\end{array}$ & 0.012 & 1.016 & 0.001 & -1.732 & 0.748 \\
\hline $\begin{array}{l}\text { GNDU Construct wise Weighted GAP } \\
\text { Score }\end{array}$ & 0.224 & 19.490 & 0.149 & -32.399 & 17.516 \\
\hline $\begin{array}{l}\text { MNIT Construct wise Unweighted GAP } \\
\text { Score }\end{array}$ & 0.012 & 0.916 & 0.732 & -2.116 & 0.364 \\
\hline $\begin{array}{l}\text { MNIT Construct wise Weighted GAP } \\
\text { Score }\end{array}$ & 0.237 & 17.232 & 14.182 & -40.366 & 8.968 \\
\hline $\begin{array}{l}\text { NITK Construct wise Unweighted GAP } \\
\text { Score }\end{array}$ & 0.012 & 1.166 & 0.166 & -2.032 & 0.669 \\
\hline $\begin{array}{l}\text { NITK Construct wise Weighted GAP } \\
\text { Score }\end{array}$ & 0.224 & 22.001 & 3.049 & -38.699 & 16.208 \\
\hline $\begin{array}{l}\text { MDU Construct wise Unweighted GAP } \\
\text { Score }\end{array}$ & 0.037 & 0.749 & 0.832 & -2.116 & 0.796 \\
\hline $\begin{array}{l}\text { MDU Construct wise Weighted GAP } \\
\text { Score }\end{array}$ & 0.749 & 14.232 & 16.116 & -40.082 & 18.836 \\
\hline
\end{tabular}


Table 6: One-Way ANOVA

\begin{tabular}{|c|c|c|c|c|c|c|}
\hline & & Sum of Squares & df & Mean Square & $\mathrm{F}$ & $\mathrm{p}$ \\
\hline \multirow{3}{*}{ R1 } & Between Groups & 11.640 & 4 & 2.910 & .847 & .498 \\
\hline & Within Groups & 326.400 & 95 & 3.436 & & \\
\hline & Total & 338.040 & 99 & & & \\
\hline \multirow{3}{*}{ R2 } & Between Groups & 9.640 & 4 & 2.410 & .626 & .644 \\
\hline & Within Groups & 366.000 & 95 & 3.853 & & \\
\hline & Total & 375.640 & 99 & & & \\
\hline \multirow{3}{*}{ R3 } & Between Groups & 6.540 & 4 & 1.635 & .461 & .763 \\
\hline & Within Groups & 336.900 & 95 & 3.546 & & \\
\hline & Total & 343.440 & 99 & & & \\
\hline \multirow{3}{*}{ R4 } & Between Groups & 5.900 & 4 & 1.475 & .339 & .850 \\
\hline & Within Groups & 412.850 & 95 & 4.346 & & \\
\hline & Total & 418.750 & 99 & & & \\
\hline \multirow{3}{*}{ R5 } & Between Groups & 10.660 & 4 & 2.665 & .732 & .571 \\
\hline & Within Groups & 345.850 & 95 & 3.641 & & \\
\hline & Total & 356.510 & 99 & & & \\
\hline \multirow{3}{*}{ R6 } & Between Groups & 4.240 & 4 & 1.060 & .239 & .915 \\
\hline & Within Groups & 421.200 & 95 & 4.434 & & \\
\hline & Total & 425.440 & 99 & & & \\
\hline \multirow{3}{*}{ R7 } & Between Groups & 5.240 & 4 & 1.310 & .345 & .846 \\
\hline & Within Groups & 360.600 & 95 & 3.796 & & \\
\hline & Total & 365.840 & 99 & & & \\
\hline \multirow{3}{*}{ R8 } & Between Groups & 17.460 & 4 & 4.365 & 1.344 & .258 \\
\hline & Within Groups & 308.500 & 95 & 3.247 & & \\
\hline & Total & 325.960 & 99 & & & \\
\hline \multirow{3}{*}{ R9 } & Between Groups & 26.640 & 4 & 6.660 & 1.845 & .126 \\
\hline & Within Groups & 343.000 & 95 & 3.611 & & \\
\hline & Total & 369.640 & 99 & & & \\
\hline \multirow{3}{*}{ R10 } & Between Groups & 3.440 & 4 & .860 & .187 & .943 \\
\hline & Within Groups & 436.000 & 95 & 4.589 & & \\
\hline & Total & 439.440 & 99 & & & \\
\hline \multirow{3}{*}{ R11 } & Between Groups & 5.240 & 4 & 1.310 & .367 & .831 \\
\hline & Within Groups & 339.350 & 95 & 3.572 & & \\
\hline & Total & 344.590 & 99 & & & \\
\hline \multirow{3}{*}{ R12 } & Between Groups & 17.100 & 4 & 4.275 & 1.048 & .386 \\
\hline & Within Groups & 387.650 & 95 & 4.081 & & \\
\hline & Total & 404.750 & 99 & & & \\
\hline \multirow{3}{*}{ R13 } & Between Groups & 8.660 & 4 & 2.165 & .563 & .689 \\
\hline & Within Groups & 365.300 & 95 & 3.845 & & \\
\hline & Total & 373.960 & 99 & & & \\
\hline \multirow{3}{*}{ R14 } & Between Groups & 6.160 & 4 & 1.540 & .358 & .837 \\
\hline & Within Groups & 408.750 & 95 & 4.303 & & \\
\hline & Total & 414.910 & 99 & & & \\
\hline \multirow{3}{*}{ R15 } & Between Groups & 37.840 & 4 & 9.460 & 2.403 & .054 \\
\hline & Within Groups & 374.000 & 95 & 3.937 & & \\
\hline & Total & 411.840 & 99 & & & \\
\hline \multirow{3}{*}{ R16 } & Between Groups & 13.660 & 4 & 3.415 & .944 & .441 \\
\hline & Within Groups & 343.700 & 95 & 3.618 & & \\
\hline & Total & 357.360 & 99 & & & \\
\hline \multirow{3}{*}{ R17 } & Between Groups & 11.260 & 4 & 2.815 & .835 & .506 \\
\hline & Within Groups & 320.450 & 95 & 3.373 & & \\
\hline & Total & 331.710 & 99 & & & \\
\hline
\end{tabular}




\section{CONCLUSION}

A comprehensive analysis revealed positive perspective of employees' towards use of digital governance for sustainable development. However, the employees were extremely unsatisfied with the facilitating conditions. Working Environment and Service Vision have been considered as foremost hindrances; and strong association measured between employees' perspective and identified structural gaps of digital governance. The study concludes that digital governance is the foremost mechanism to achieve sustainability, provided involvement of employees (back and front end) is ensured from the planning phase itself.

\section{AUTHORS' CONTRIBUTIONS}

The authors proposed integration of service vision among all level of administration at the planning stage to enhance the efficiency, synergy and social influence of digital governance.

\section{ACKNOWLEDGMENTS}

The authors acknowledge the help of the open source society for providing software's access required for statistical analysis. The authors acknowledge the immense help received from the scholars whose articles are cited and included in references to this manuscript. The authors are also grateful to authors/editors/publishers of all those articles, journals and books from where the literature for this article has been reviewed and discussed. The authors acknowledge the immense help of the respondents. The study was self-funded and there is no conflict of interest.

\section{REFERENCES}

[1] Barbosa L.S., Digital Governance for Sustainable Development. In: Kar A. et al. (eds) Digital Nations - Smart Cities, Innovation, and Sustainability. Lecture Notes in Computer Science, Springer, 10595: 2017, pp. 85-93. DOI: https://doi.org/10.1007/978-3-319-685571_9

[2] Josh Tong, Key components of digital governance in organizations. https://www.joshtong.io/blog/2017/11/14/keycomponents-of-digital-governance-inorganizations. 2017, Accessed 20 January 2020
[3] UN Report, Investing in e-governance for sustainable development." United Nations University.

https://unu.edu/news/news/investing-in-egovernance-for-sustainable-development.html 2011, Accessed 22 March 2020

[4] EurekAlert and AAAS, Science, government, and business leaders say achieving SDGs requires digital governance. EurekAlert and AAAS. July 2nd. 2020, https://www.eurekalert.org/pub_releases/202007/tca-sga063020.php. Accessed 13 August 2020

[5] Rama Krushna Das and Harekrishna Mishra., Smart E-Governance and Sustainable Development: Strategic Alignment Assessment Framework. ICEGOV '18: Proceedings of the 11thInternational Conference on Theory and Practice of Electronic Governance.2018, pp. 690-692.

DOI: https://doi.org/10.1145/3209415.3209468

[6] Barbara, Digital technology for the sustainable development goals. DiPLO, https://www.diplomacy.edu/blog/digitaltechnology-sdgs, 2018, Accessed 20 January 2020

[7] Digital Future Society Towards Agenda 2030, Digital Future Society and the Sustainable Development Goals. Digital Future Society.2019, pp. 1-23. https://digitalfuturesociety.com/report/towardsagenda-2030\%. Accessed 25 January 2020.

[8] Tomasz Janowski, Implementing Sustainable Development Goals with Digital Government Aspiration-capacity gap. Government Information Quarterly 33(4):2016, pp. 603-613. DOI: https://doi.org/10.1016/j.giq.2016.12.001.

[9] OECD. 2020. Governance for sustainable and inclusive digital government. Digital Government in Mexico : Sustainable and Inclusive Transformation. OECD iLibrary. https://www.oecd-ilibrary.org/sites/11d7f4bden/index.html?itemId=/content/component/11d 7 f4bd-en. 2020 Accessed 20 January 2020

[10] Sahar E-Vahdati, Norhayah Zulkifli, Zarina Zakaria, Corporate governance integration with sustainability: a systematic literature review. 
Corporate Governance 19(2):2018, pp. 255-269. DOI: https://doi.org/10.1108/CG-03-2018-0111

[11] Linkov, Trump, Poinsatte Jones, Florin., Governance Strategies for a Sustainable Digital World. Sustainability 10(2): 2018, p 440.DOI: https://doi.org/10.3390/su10020440.

[12] Egidijus Barcevičius, Guoda Cibaitè, Cristiano Codagnone, Vaida Gineikyte, Luka Klimavičiūtè, Giovanni Liva, Loreta Matulevič, Gianluca Misuraca, Irene Vanini., Exploring Digital Government transformation in the EU. JRC Science for Policy Report.2019, pp. 1-96. DOI:10.2760/17207.

[13] Stocker F, de Arruda MP, deMascena KMC, Boaventura JMG, Stakeholder engagement in sustainability reporting: A classification model. Corp SocResponsib Environ Manag 27:2020, pp. 2071-2080. DOI: https://doi.org/10.1002/csr.19472080 STOCKER ET AL.

[14] Yadav, Saini, Yadav, Analysing and securing the sustainability of e-Government projects from technical aspect using employees perspective approach. International Journal of Information Technology: 2019, pp. 1-13. DOI: https://doi.org/10.1007/s41870-019-00333-7. Accessed 28 March 2020

[15] Goel Sameer, Dwivedi Rajeev; and Sherry Arun, Role of Key Stakeholders in Successful E-Governance Programs: Conceptual Framework. Proceedings of the Eighteenth Americas Conference on Information Systems, Seattle, Washington. 2012, pp. 1-9. http://aisel.aisnet.org/amcis2012/proceedings/E Government/19.

[16] Marche and McNiven, EGovernment and eGovernance: The future isn't what it used to be: Revue comedienne des sciences del' administration. Canadian Journal of Administrative Sciences 20(1):2033, pp. 74-86. https://search.proquest.com/docview/20488966 9? accountid $=195353$.

[17] Ray and Mukherjee, Development of a framework towards successful implementation of eGovernance initiative in health sector in India. International Journal of Health Care Quality Assurance 20:2007, pp. 464-483.
[18] Moon, The Evolution of e-Government Among Municipalities: Rhetoric or Reality?. Public Administration Review 62(4):2003, pp. 424433.

[19] NeSDA 2019, National e-Governance Service Delivery Assessment 2019, e-Governance Landscape - India's Transformative Journey. New Delhi : Department of administrative reforms and public grievances, Ministry of personal grievances and pensions, Government of India. 2020, pp. 1-180. https://nesda.gov.in/publicsite/NeSDA 2019 Fi nal Report.pdf.

[20] S.S. Rout, B.B. Misra, \& S. Samanta, Load Allocation in Academic Environment: A Multi Objective PSO Approach, GSTF Journal on Computing (JoC) 3(4) (2014) 9-20. https://doi.org/10.7603/S40601-013-0036-7

[21] P.K. Suar, SR Samanta, Going Cashless Behind the Wheels Digital Options for SRTO, Solid State Technology 63 (5) (2020)

[22] P.K. Raut, J. R. Das, J. Gochhayat, K. P. Das, Influence of workforce agility on crisis management: Role of job characteristics and higher administrative support in public administration, Materials Today: Proceedings (2021). https://doi.org/10.1016/j.matpr.2021.08.121. 